\title{
PENINGKATAN KAPASITAS PRODUKSI : PEMBUATAN BELT CONVEYOR DAN OVEN PERMANEN PADA UPGRADING BRIKET ARANG BATOK KELAPA
}

\author{
Hendrato Setiabudi Nugroho ${ }^{1)}$, Diyah Candra Anita ${ }^{2)}$, Retno Wulandari ${ }^{3)}$ \\ 1) Fakultas Ekonomi Ilmu Sosial dan Humaniora Universitas 'Aisyiyah Yogyakarta \\ e-mail: hendrato.nugroho@unisayogya.ac.id \\ ${ }^{2)}$ Fakultas Ilmu Kesehatan Universitas 'Aisyiyah Yogyakarta \\ e-mail: diyah.candra@gmail.com \\ ${ }^{3)}$ Fakultas Pertanian Universitas Muhammadiyah Yogyakarta \\ E-mail: wulandari1102@yahoo.com
}

\begin{abstract}
Abstrak
Globalisasi sudah tidak bisa dihindarkan lagi dan harus dihadapi oleh para pengusaha Indonesia terutama UKM (Usaha Kecil dan Menengah). Bagi UKM, pasar global memberikan peluang sekaligus tantangan. Oleh karenanya, diperlukan sebuah metode yang tepat bagi UKM untuk dapat menghadapi tantangan tersebut. Tujuan yang ingin dicapai dalam program PPPE Upgrading Briket Arang Batok Kelapa Berorientasi Ekspor ini adalah sebagai berikut: (1) memacu pertumbuhan ekspor produk UKM di Indonesia melalui pertumbuhan pasar yang kompetitif; (2) mempercepat alih teknologi dan manajemen masyarakat perguruan tinggi ke masyarakat UKM; (3) mengembangkan sinergi antara UKM, Perguruan Tinggi, Pemerintah Daerah dan masyarakat. Metodologi yang dilakukan guna mencapai tujuan tersebut adalah melalui rapat koordinasi dan diskusi ilmiah, serta pembuatan alat dengan alih teknologi guna efisiensi produksi. Hasil implementasi adalah : (1) meningkatkan persentase volume ekspor dengan perluasan unit produksi dan penambahan karyawan; (2) tercapainya efisiensi produksi briket arang batok kelapa sekaligus alih teknologi dengan membuat mesin belt conveyor dan oven permanen, serta peralihan bahan bakar selama pengeringan.
\end{abstract}

Kata Kunci : briket arang, teknologi tepat guna, belt conveyor, oven permanen

\section{PENDAHULUAN}

Globalisasi sudah tidak bisa dihindarkan lagi dan harus dihadapi oleh para pengusaha Indonesia terutama UKM (Usaha Kecil dan Menengah). Meski banyak tantangan yang harus dihadapi, UKM sebenarnya mempunyai peluang untuk memperoleh keuntungan di pasar global. Dengan strategi yang tepat dan benar, UKM Indonesia dapat bersaing dengan UKM-UKM di negara-negara berkembang lainnya khususnya di Asia Tenggara untuk masuk dan diterima di pasar global (Downing \& Campbell, 2014).

Berbagai ancaman yang membayangi UKM yang mencoba masuk ke pasar global sebenarnya signifikan. Mereka terancam ke dalam pertarungan yang justru menuju ke dasar jurang kehancuran. Hal ini disebabkan oleh beberapa faktor, yaitu saling menjatuhkan harga jual sesama produsen padahal biaya bahan baku yang semakin mahal, harga jual dari UKM sejenis dari luar negeri jauh lebih murah, tingginya upah tenaga kerja dan minimnya dukungan pemerintah sendiri (Arfani, 2013).
Namun bagi UKM yang sukses masuk pasar global, keuntungan yang diperoleh sangat besar terutama dari selisih kurs mata uang. Hal ini disebabkan biaya produksi memakai mata uang rupiah sedangkan keuntungan yang diterima menggunakan mata uang dollar. Sehingga keuntungan yang diterima berkali-kali lipat. Asalkan tidak ada resesi dunia yang mengancam. Hal ini yang menyebabkab terkadang banyak yang tergiur dengan keuntungan dari pasar global namun tidak tahu caranya bertahan di pasar global justru gulung tikar lebih cepat (Arfani, 2013).

Oleh karenanya diperlukan sebuah metode yang tepat dan sistematis yang dapat digunakan oleh UKM untuk dapat masuk dan bertahan di pasar global. Metode tersebut adalah Global Value Chain atau sering disingkat GVC. Sebuah metode yang sudah diterapkan di berbagai negara dan terbukti keberhasilannya. GVC adalah cara yang mudah diterapkan untuk UKM sehingga ia dapat segera naik ke level yang lebih tinggi. Keberhasilan dari metode ini adalah dapat diterapkan pada UKM yang berorientasi ekspor (Kula et.al., 20016). 
Salah satu UKM yang sedang berkembang dan mempunyai peluang ekspor yang cukup besar di pasar global adalah briket arang batok kelapa. Permintaan akan briket arang mulai masuk ke Indonesia pada awal tahun 2000-an. Produk briket banyak dibutuhkan di Eropa, Amerika dan Timur Tengah. Di Eropa dan Amerika, briket arang batok kelapa dibutuhkan sebagai bahan bakar untuk barbeque Sedangkan di Timur Tengah, briket arang digunakan sebagai bahan bakar untuk rokok shisha Hal ini yang mendorong permintaan dari luar negeri dalam jumlah yang sangat banyak sehingga memunculkan pengusaha-pengusaha briket arang batok kelapa (Dunn et.al., 2006).

Di Yogyakarta, terdapat sejumlah UKM yang memproduksi briket arang batok kelapa, diantaranya adalah BriqCo dan d'Briquettes. Keduanya berada di Kabupaten Bantul. BriqCo berada di Kecamatan Sewon sedangkan d'Briquettes berada di Kecamatan Pleret. Dua UKM ini terbilang cukup sukses untuk ukuran industri kecil yang menembus pasar global. Mereka berhasil mengubah batok kelapa yang awalnya tidak begitu dilirik menjadi peluang yang luar biasa. Pemiliknya bahkan orang desa biasa yang awalnya tidak paham dengan pasar global. Bukan sarjana yang mempelajari pasar global.

UKM BriqCo mulai dirintis oleh Novi Setiawan sejak tahun 2009. Berawal dari usaha coba-coba, Novi membuat briket arang batok kelapa. Usaha ini muncul setelah Novi mendapatkan tawaran dari temannya yang mendapat pesanan dari luar negeri. Setelah itu Novi selalu mendapat pesanan dari luar negeri.

UKM d'Briquettes mulai dirintis oleh Danang Setiyo pada tahun 2012. Sebelumnya Danang adalah salah satu karyawan pada BriqCo. Kemudian Danang memberanikan diri mencoba mengembangkan usahanya sendiri dan memperoleh dukungan dari Novi.

Permasalahan utama yang tampak untuk UKM BriqCo adalah kesulitan dalam mengejar target produksi lebih dari 2 ton perhari karena tidak ada mesin yang menunjang. Sedangkan untuk UKM d'Briquettes, kendala yang dihadapi adalah mahalnya bahan bakar yang digunakan untuk pengeringan yaitu gas LPG dengan rerata biaya bahan bakar Rp. 7.500.000,00 per hari.

\section{METODE KEGIATAN}

Kegiatan yang dilakukan disesuaikan dengan pemecahan permasalahan. Guna memecahkan permasalahan kapasitas produksi, pengusul bersama mitra melakukan metode: (1) Metode rapat dan diskusi untuk menentukan peralatan primer yang akan diadakan pada tahun pertama kegiatan PPPE; (2) Metode perancangan dan pembuatan alat dengan teknologi tepat guna.

Melalui metode tersebut disepakati bahwa alat yang akan diadakan pada tahun pertama kegiatan PPPE adalah belt conveyer untuk efisiensi pemotongan pada pabrik BriqCo dan oven permanen untuk efisiensi bahan bakar pada pabrik d'Briquettes.

\section{HASIL DAN PEMBAHASAN}

Dari permasalahan yang dijumpai dan disepakati akan diselesaikan dengan manajemen Briqco adalah pengadaan mesin/alat belt conveyor untuk meningkatkan kecepatan proses produksi briket arang batok kelapa. Beberapa tahap yang dilakukan dalam pengadaan alat tersebut adalah :

a. Pembuatan design alat belt conveyor yang bentuk maupun ukuran disesuaikan dengan kebutuhan proses, kecepatan proses dan ketersediaan tempat di pabrik;

b. Pengadaan material alat berupa besi, karpet karet, roda pemutar, karet penggerak roda dan motor penggerak. Material ini dibelanjakan dari toko besi dan toko peralatan bengkel mesin;

c. Setting alat, dengan cara memotong dan mengelas besi sedemikian rupa hingga menyerupai meja yang akan dijadikan sebagai tempat kerja. Kemudian memasang karpet karet yang dijadikan sebagai conveyor dan menghubungkannya dengan motor penggerak. Perlu dipasang roda transmisi untuk menyesuaikan kecepatan putaran motor penggerak dengan kecepatan gerak conveyor sesuai kebutuhan;

d. Pemasangan pisau yang terbuat dari besi yang akan berputar memotong adonan sesuai dengan panjang briket yang dibutuhkan, sehingga ukuran setiap briket akan sama dan presisi;

e. Pemasangan plat pengarah yang berfungsi untuk mengarahkan sisa potongan adonan ke tempat penampungan sehingga tidak bercampur dengan briket arang yang akan dikeringkan. 


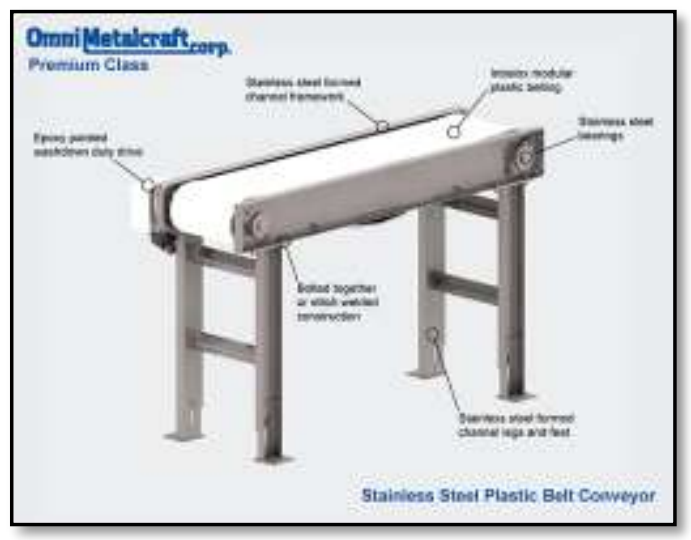

Gambar 1. Desain belt conveyor yang Dirujuk

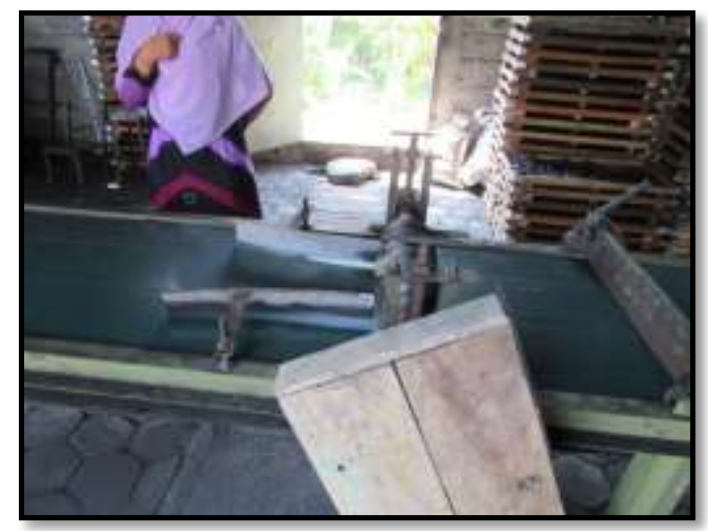

Gambar 2. Belt conveyor yang telah terpasang

Belt conveyor yang dibuat sudah dievaluasi penggunaannya selama dua bulan. Hasil evaluasi menunjukkan belt conveyor mampu meningkatkan kecepatan produksi sampai dengan $85 \%$. Rata-rata produksi briket meningkat menjadi $500 \mathrm{~kg} / \mathrm{jam}$, dari semula $300 \mathrm{~kg} / \mathrm{jam}$. Peningkatan kecepatan produksi ini membuat pekerjaan memotong dan mencetak briket yang seharusnya dilakukan selama 6 jam dapat direduksi, sehingga hal tersebut dapat dikerjakan dalam waktu 4 jam.

Sedangkan permasalahan yang dijumpai pada d'Briquette adalah kurangnya kapasitas pengeringan, yang selama ini hanya menggunakan beberapa mesin oven berkapasitas kecil. Untuk itu disepakati dibuat oven permanen dengan kapasitas yang lebih besar. Tahapan yang dilakukan adalah sebagai berikut:

a. Tahap persiapan, dengan melakukan pembersihan tempat yang akan dibangun oven permanen dan pembelanjaan material berupa batako, pasir, semen, besi rangka, plat besi, pipa cerobong, drum pembakaran. Pengadaan material ini diperoleh dari toko bahan bangunan; b. Tahap pembangunan oven permanen, dengan mendirikan bangunan batako bersegi empat dan berpintu lebar yang terbuat dari plat besi. Atap terbuat dari cor semen untuk mengurangi hilangnya panas hasil pembakaran;

c. Tahap pemasangan alat pembakaran, dengan memasang drum-drum pembakaran yang akan digunakan untuk menempatkan bahan bakar berupa oli bekas yang akan disemprotkan ke tungku untuk dibakar. Di atas tungku dipasang cerobong yang berfungsi untuk mencegah kobaran api ke segala arah yang akan mengakibatkan terbakarnya briket arang, dan juga untuk mengarahkan pembuangan asap keluar oven. Cerobong dibuat dengan ketinggian yang cukup, sehingga asap sisa pembakaran diharapkan tidak mengganggu masyarakat sekitar.

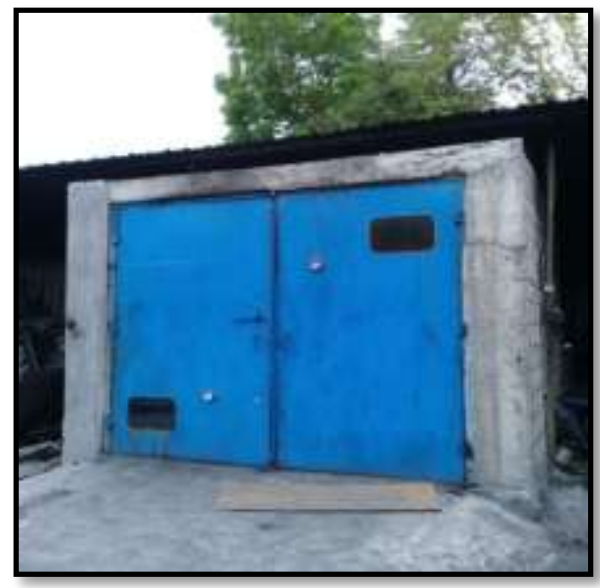

Gambar 3. Oven permanen yang telah jadi

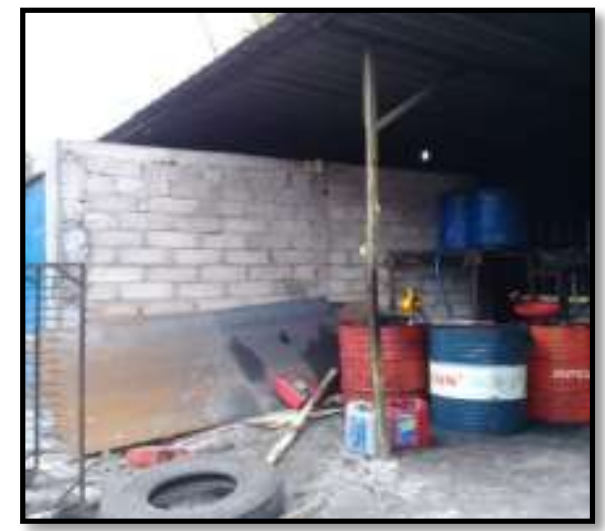

Gambar 4. Bahan bakar oli bekas

Oven permanen d'Briquettes jadi secara sempurna pada bulan Agustus 2018, dan sudah beroperasional pada awal bulan September 2018. Evaluasi yang dilakukan pada awal bulan Oktober menunjukkan bahwa penggunaan oven 
permanen tersebut telah mereduksi $30 \%$ biaya operasional untuk bahan bakar. Biaya pengadaan bahan bakar yang semula Rp. 7.500.000,00 per bulan tereduksi, sehingga biaya operasional bahan bakar saat ini adalah Rp. 4.500.000,00 per bulan.

\section{KESIMPULAN}

Hasil peningkatan produksi yang dihasilkan dari pembuatan belt conveyor dan oven permanen ini adalah :

1. Hasil yang dicapai dari pembuatan belt conveyor pada industri briket arang batok kelapa Briqco adalah efisiensi waktu proses produksi yang semakin cepat. Sebelum digunakannya alat tersebut untuk memproduksi 2 ton briket dibutuhkan waktu 6 jam kerja dalam sehari. Namun setelah digunakannya alat ini, hanya membutuhkan waktu 4 jam untuk memproses 2 ton briket. Terdapat penghematan waktu produksi mencapai $33 \%$ dari waktu digunakan sebelumnya.

Keuntungan yang dicapai saat ini dari berkurangnya waktu produksi ini adalah penghematan biaya tenaga kerja langsung di pabrik. Semula Briqco harus mempekerjakan dan membayar penuh gaji buruh dalam satu hari, namun sekarang untuk menghasilkan sejumlah produksi yang sama Briqco cukup mempekerjakan dan membayar gaji buruh lebih sedikit.

Sebenarnya dari efisiensi produksi ini dapat digunakan untuk melakukan proses produksi lebih lanjut. Namun karena keterbatasan bahan baku dan terbatasnya kapasitas oven pengering maka kapasitas produksi belum ditambah untuk saat ini. Untuk itu, kedepan perlu dilakukan penambahan bahan baku srcap arang batok kelapa dan pembautan oven dengan kapasitas lebih besar untuk mampu meningkatkan jumlah produksi. Sehingga diharapkan Briqco akan mampu memenuhi permintan pasar yang terus meningkat.

2. Pada pembuatan oven permanen pada industri briket arang batok kelapa d'Briquette, hasil yang dicapai saat ini adalah peningkatan kapasitas mesin pengeringan briket. Sehingga dengan waktu yang sama bisa menghasilkan briket arang kering dengan jumlah yang lebih banyak. Bila menggunakan oven semi permanen yang dimiliki sebelumnya hanya dapat mengeringkan 5 ton briket arang per hari, maka dengan menggunakan oven permanen ini dapat digunakan untuk mengeringkan 8 ton briket arang perhari.

Selain itu dengan menggunakan tungku pembakaran yang baru bisa dihemat bahan bakar yang semula menggunakan gas elpiji dan sekarang menggunakan oli bekas yang harganya jauh lebih murah. Penghematan yang dicapai dari beralihnya bahan bakar ini mencapai $70 \%$ untuk waktu pembakaran yang sama. Sehingga untuk penggunaan oven permanen ini d'Briquette mendapatkan keuntungan ganda yaitu peningkatan kapasitas produksi dan efisiensi penggunaan bahan bakar.

\section{REFERENSI}

Arfani, RN., 2013, GVC (Global Value Chain) Framework : Perspective \& Practices to Comprehend Local - Global Nexus in Trade Relations, Makalah untuk Short Course Series in International Trade (SCSIT) PSPD (Pusat Studi Perdagangan Dunia), UGM : Yogyakarta.

Downing J., Campbell, R., 2014, Briefing paper, The Value Chain Framework, USAID, https://www.maxwell.syr.edu/uploadedFiles/exe d/sites/pgppm/Program_Readings/10_21_abonyi -Value_Chain_Framework.pdf

Dunn, E., Sebstad, J., Batzdorff, L., and Parsons H., 2006, Lessons Learned on MSE Upgrading in Value Chains : A Synthesis Paper, AMAP BDS Knowledge and Practice, microREPORT \#71, USAID/G/EGAT/MD, Washington, D>D> :ACDI/VOCA.

Kula, Olaf, Downing, J., Field, M., 2006, Globalization and the Small Firm : A Value Chain Approach and Poverty Reduction, AMAP BDS Knowledge and Practice, microREPORT \#42, USAID/G/EGAT/MD, Washington, D.C. : ACDI/VOCA. 